\title{
Beneficial Use of Scrap Tires for Retardation of Pesticide Movement in Golf Courses \\ Jae K Park ${ }^{1 *}$ and Changqing $\mathrm{Ye}^{2}$
}

${ }^{1}$ Department of Civil and Environmental Engineering, University of Wisconsin-Madison, Madison, Wisconsin, USA

${ }^{2}$ School of Public Health, Nantong University, China

\begin{abstract}
Tire rubber has been found to adsorb pesticides and nitrate, and remove phosphorus by precipitation with iron released from steel wire. Golf courses are known to release pesticides and nutrients such as nitrogen and phosphorous. The feasibility of using tire rubber as an adsorbent for pesticides in golf courses was evaluated using statistical and mathematical methods. Empirical equations were proposed to predict the required tire rubber layer thickness to remove various pesticides under different conditions. It was found that a $20 \mathrm{~cm}$ thick tire rubber layer was capable of removing $\geq 90 \%$ for 37 out of 51 pesticides. Three of the 51 pesticides required a $>200 \mathrm{~cm}$ thick tire rubber layer, yet had high solubility and short half-life. By using scrap tires for the mitigation of pesticides and fertilizers, golf courses may be able to realize the dual benefits of waste utilization and reduced environmental contamination.
\end{abstract}

Keywords: Adsorption; Fertilizers; Golf course; Ground rubber; Pesticides; Scraps tires

\section{Introduction}

In 2007, 303 million scrap tires were generated in the United States (US) [1]. Tire-derived fuel (TDF) accounts for $54 \%$ of the recovered tires, followed by ground rubber (17\%) and civil engineering applications (12\%) such as subgrade fill and embankment, backfill for walls and bridge abutments, subgrade insulation for roads, landfills, septic system drain fields, etc. The total recycling rate of tires in 2011 is $44.6 \%$ [2]. Thus, more effort should be made to improve the recycling rate of tires. Tire chips are not a hazardous waste $[3,4]$. The concentrations of metals leaching from tire chips were all below the National Primary Drinking Water Regulation maximum contaminant levels (MCLs) [5] although the concentrations of iron and manganese exceeded MCLs of the National Secondary Drinking Water Regulation that is the guidance for nuisance chemicals especially at low $\mathrm{pH}[3,6,7]$. Volatile and semi-volatile organic compounds leached from tire chips located above the water table were below detection limits but those below the water table were detectable at trace levels $[3,8,9]$. Studies on leachate from crumb rubber showed no deleterious effects to the environment $[10,11]$.

Styrene-butadiene co-polymer (SBR) gaskets used as drinking water pipe joint seal were found to adsorb large quantities of organic compounds $[12,13]$. SBR gaskets have the similar composition to tire rubber $(70 \%$ SBR, $15 \%$ steel, and $15 \%$ textile fiber for car tire [14]). Therefore, tire rubber has been proposed to use as an adsorbent in vapor phase [15], in aqueous phase [16,17], and in slurry cut-off walls [18]. Kim et al. [17] found that ground rubber had 1.1 4.4\% of volatile organic compound sorption capacity of granular activated carbon. Park et al. [19] confirmed that tire chips in field cell tests significantly adsorbed arsenic, cobalt, lead, nickel, and gasoline components. Gupta et al. [20] found $\geq 95 \%$ nickel removal by scrap tire.

Ground rubber mixed with compost was able to remove hydrogen sulfide effectively even at $-30^{\circ} \mathrm{C}$ whereas a wood-chip packed biofilter failed at this temperature [21]. Wang [22] also found removal of hydrogen sulfide by tire derived rubber particles. Tire rubber was proposed to remove nitrate in fertilizer leaching from golf course putting greens [23]. Park et al. [19] concluded that although tire rubber leaches a few heavy metals and organic compounds, tire rubber is capable of adsorbing toxic organic and inorganic compounds when the concentrations in the surrounding environment are high. Previous studies strongly indicate that tire rubber can be a good material for removing toxic contaminants while recycling scrap tires. It was also found that the constructed wetlands packed with shredded steel-belted tire had 17 to $60 \%$ increases in the phosphorus removal efficiency [24] and almost twice as much [25] compared with the wetlands packed with gravel.

Scrap tire chips and ground rubber have been successfully used in a number of civil engineering applications. Scrap tires have been proposed and used for lightweight fill for embankments and retaining walls [26-30], drainage layers for roads and septic tank leach fields [31], and drainage and filter layers in landfills [19]. In nearly half of Organization of Economic Cooperation and Development (OECD) countries, nutrient and pesticide concentrations in surface and groundwater in agricultural areas exceed national recommended limits for drinking water standards [32]. Golf courses use pesticides and fertilizers to provide a healthy playing condition for the game. Cohen et al. [33] claimed that widespread and/or repeated water quality impacts by golf courses did not occur at 36 golf courses studied. Snow [34] stated that nitrogen leaching amounted to $1 \%$ to $8 \%$ and pesticide leaching was up to $18 \%$. Köck-Schulmeyer et al. [35] found considerably high concentrations of pesticides in raw wastewaters (up to $684 \mathrm{ng} / \mathrm{L}$ for diazinon) and their persistence in the treated waters after conventional secondary (and even tertiary) wastewater treatment, indicating widespread pollution and persistency of pesticides. King et al. [36] found that the turfgrass environment contributed increased nitrate/nitrite and phosphorus loads to nearby streams. Swancar [37] detected pesticides at trace levels ( $45 \%$ of all occurrences) and under the maximum contaminant levels ( $92 \%$ of all occurrences)

*Corresponding author: Jae K Park, Department of Civil and Environmental Engineering, University of Wisconsin-Madison, 1415 Engineering Drive, Madison, Wisconsin 53706, USA, Tel: +16082627247; E-mail: jkpark@wisc.edu

Received January 27, 2016; Accepted April 04, 2016; Published April 11 2016

Citation: Park JK, Ye C (2016) Beneficial Use of Scrap Tires for Retardation of Pesticide Movement in Golf Courses. Adv Recycling Waste Manag 1: 107. DOI: 10.4172/2475-7675.1000107

Copyright: (C) 2016 Park JK, et al. This is an open-access article distributed under the terms of the Creative Commons Attribution License, which permits unrestricted use, distribution, and reproduction in any medium, provided the original author and source are credited. 
in groundwater on seven of nine golf courses studied in Florida and in $52 \%$ of the samples. In six occurrences, concentrations of arsenic, bentazon, or acephate in groundwater were above the MCLs or guidance concentration. Atrazine, bromacil, diazinon, diuron, fenamiphos, metalaxyl, oxydiazon, and simazine were detected at least at one site. Kearns and Prior [38] claimed that the most regularly used pesticides leached readily in soil and were found in groundwater samples in Northern Ireland. The majority of compounds applied are listed as being toxic to wildlife with some also being very toxic to the aquatic environment and having adverse effect to human health.

Li et al. [39] found that chlorothalonil and phosfolan-methyl from golf courses influenced the surrounding water environment greatly, chemical oxygen demand $\left(\mathrm{COD}_{\mathrm{cr}}\right)$ reached a maximum concentration of $122 \mathrm{mg} / \mathrm{L}$, and total nitrogen was up to $17.8 \mathrm{mg} / \mathrm{L}$, exceeding the surface water environment quality standards of grade $\mathrm{V}$ in China. Haith [40] stated that five of the 37 pesticides resulted in potential acute risk to invertebrates and fish or algae when applied at label rates on lawns, fairways, or greens. The impact to the surrounding environment was often claimed to be minimal if pesticides are applied carefully to golf courses. However, greater levels of safety and reliability could be achieved by implementing active pollutant-control measures. In this sense, tire rubber may be used in golf courses to mitigate the release of pesticides and fertilizers to the surrounding environment.

The objectives of this study were to evaluate the feasibility of using tire chips and ground tires in tees, fairways, and greens in various methods and determine the optimum tire rubber thicknesses for removals of pesticides. Statistical analysis was performed using published data to determine the relationships among various biological, physical, and chemical properties of pesticides used in golf courses. Empirical equations were developed to assess the pesticide removal efficiency by tire rubber and determine the tire rubber layer thickness. Lastly, recommendations of best practices for the use of scrap tires in golf course construction are included.

\section{Fate and transport of pesticides applied to golf courses}

In general, the following six processes affect the fate of chemicals applied to golf courses [41]:

\section{Solubilization by water,}

2. Sorption by soil mineral and organic matter,

3. Degradation by soil microorganisms,

4. Chemical degradation and photo-decomposition,

5. Volatilization and evaporation,

\section{Plant uptake.}

The relative importance of each process is controlled by the physicochemical property, temperature, water content, soil type, porosity, and advective transport. The mobility of a chemical in the environment is determined dominantly by the degree of adsorption to soil organic matter. If the soil organic carbon-water partition coefficient, $K_{o c}$, is high, the chemical tends to have a high affinity to the soil matrix by adsorption.

Transportation of pesticides and fertilizers typically occurs through runoff and leaching. Runoff is frequently caused by a storm event or heavy irrigation and is often the major cause of surface water pollution. Leaching occurs when water infiltrates vertically through the soil and potentially into groundwater. To minimize these chemical transportation modes, a capture layer may be installed along the runoff zone or infiltration zone to help removing pesticides and fertilizers. Given the high adsorptive capacity of tire rubber, it can be an efficient and cost-effective material for use in these chemical control installations. Park et al. [16] derived the following equation to determine the thickness of a tire rubber layer required to remove a given amount of a chemical:

$$
d=1.00 \times 10^{-5} \times \frac{M_{a}}{(1-n)^{\cdot} \rho_{t}}
$$

where $M_{a}$ is the required mass of tire rubber per unit area $(\mathrm{kg} / \mathrm{ha})$, $n$ is the porosity of the tire rubber layer, and $\rho_{t}$ is the density of tire rubber, $\mathrm{g} / \mathrm{cm}^{3}$. The required mass of tire rubber can be estimated as follows:

$$
M_{a}=\frac{f \cdot Q_{r} \cdot t_{d} \rho_{t} \times 10^{3}}{(1-f) \cdot K_{d}}
$$

$$
K_{d}=f_{o c} \cdot K_{o c}
$$

where $f$ is the fraction of a pesticide to be removed, $Q_{r}$ is the infiltration rate $\left(\mathrm{m}^{3} / \mathrm{ha} / \mathrm{yr}\right), t_{d}$ is the design life of the tire rubber layer, yrs, $K_{d}$ is the soil-pesticide partition coefficient $(\mathrm{L} / \mathrm{kg}), f_{o c}$ is the organic carbon fraction in tire rubber, and $K_{o c}$ is the soil organic carbonwater partition coefficient $(\mathrm{L} / \mathrm{kg})$. Using these equations, it is possible to calculate the required thickness of tire rubber layers to prevent the transportation of pesticides and fertilizers through runoff and infiltration.

\section{Relationships among physical/chemical properties of pesticides}

Balogh and Walker [42] summarized solubilities $(S)$, soil organic carbon-water partition coefficients $\left(K_{o c}\right)$, octanol-water partition coefficients $\left(K_{o w}\right)$, degradation rates in the soil root zone $\left(K_{s}\right)$, and half-life $\left(t_{0.5}\right)$ for various pesticides. Listed were nine insecticides and nematicides, 15 fungicides, and 27 herbicides, totaling 51 pesticides. The logarithmic relationships among $S, K_{o c}, K_{o w}, K_{s}$ and $t_{0.5}$ were determined using the values tabulated by Balogh and Walker. If the values were given as a range, the average value was used. After reviewing the properties of 51 pesticides listed, anilazine, benefin, glyphosate acid, glyphosate amine salt, and MSMA sodium salt were excluded from the regression analysis due to inconsistency in chemical and biological properties. The properties of these pesticides are summarized in Table 1.

Organic compounds must be released to solution to be degraded by microorganisms since the biodegradation rate of organic compounds is controlled by bioavailability when the organic compounds have a strong affinity for surfaces in the environment [43]. In this regard, anilazine having a high $K_{o c}$ value of 1,070 3,000 and a short half-life of $0.5 \sim 1$ is an exceptional outlier and was thus excluded. It is also generally known that the $K_{o c}$ value tends to decrease as solubility increases for an organic compound considering the chemical properties. Thus, glyphosate acid, glyphsate amine salt, and monosodium methyl arsenate (MSMA) sodium salt having both high $S$ and $K_{o c}$ values were also excluded in the regression analysis. The extremely high half-life of 1,000 days for MSMA sodium salt may be due to the presence of arsenic which

\begin{tabular}{|c|c|c|c|c|}
\hline Pesticides & $\begin{array}{c}\text { Solubility } \\
(\boldsymbol{S}), \mathbf{m g} / \mathbf{L}\end{array}$ & $\boldsymbol{K}_{\text {oc }}, \mathbf{L} / \mathbf{k g}$ & $\begin{array}{c}\text { Degradation rate } \\
\left(\boldsymbol{K}_{\boldsymbol{s}}\right) \text {, day }\end{array}$ & $\begin{array}{c}\text { Half-life }\left(\boldsymbol{t}_{\boldsymbol{0} .5}\right) \\
\text { days }\end{array}$ \\
\hline $\begin{array}{c}\text { Anilazine } \\
\text { Glyphosate, }\end{array}$ & 8.0 & $1,070 \sim 3,000$ & $0.693 \sim 1.386$ & $0.5 \sim 1$ \\
acid & 12,000 & 2,640 & 0.054 & 44 \\
Glyphosate & 900,000 & 24,000 & 0.0185 & 40 \\
amine salt & 985,000 & 200,000 & 0.001 & 1,000 \\
MSMA sodium & & & & \\
salt & & & & \\
\hline
\end{tabular}

Table 1: Pesticides not included in the regression analysis. 
is toxic to microorganisms. Glyphosate, a highly soluble chemical is also readily adsorbed to solids once released. Because of the limited bioavailability by strong adsorption, it also has a low degradation rate. Unlike other pesticides, the main pathway of glyphosate transport is through the movement of fine particles containing glyphosate. This may lead to a potentially high level of contamination once fine particles reach surface water and groundwater.

Figure 1 shows the relationship between $K_{o c}$ and $S$. As expected, there was a strong correlation with an $\mathrm{r}^{2}$ value of 0.757 . This strong relationship justifies the exclusion of anilazine from regression analysis. Figure 2 shows the relationship between $K_{o c}$ and $K_{o w}$. Although there were many missing $K_{o w}$ values, the relationship was strong with the $\mathrm{r}^{2}$ value of 0.878 . It is suggested that missing $K_{o w}$ values be determined for pesticides and corrected for the $K_{o c}$ value and subsequent $K_{d}$ value of specific interest of soil or adsorbent to improve the accuracy of the prediction.

Figure 3 shows the relationship between $S$ and $K_{s}$. Figure 4 shows the relationship between $S$ and $t_{0.5}$. The relationship between $S$ and $t_{0.5}$ was slightly better than that between $S$ and $K$. For chemicals that the values of $K_{s}$ and $t_{0.5}$ are unknown, they can be estimated from the $K_{o c}$ value of a chemical using the relationship shown in Figures 5 and 6 , respectively. The regression equations between $S$ and $K_{o c}, K_{o c}$ and $K_{o w}$, $S$ and $K_{s}, S$ and $t_{0.5}, K_{o c}$ and $K_{s}$, and $K_{o c}$ and $t_{0.5}$ are summarized with the $\mathrm{r}^{2}$ values in Table 2 .

Using the regression equations shown in Table 2, it is possible to predict the required tire layer thickness and thus mobility if $S$ or $K_{o w}$ is

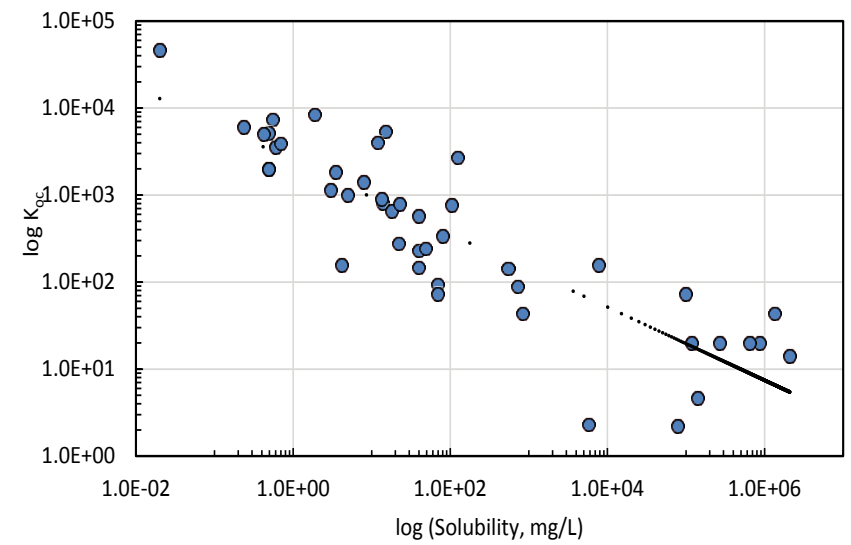

Figure 1: Relationship between solubility and soil organic carbon-water partition coefficient.

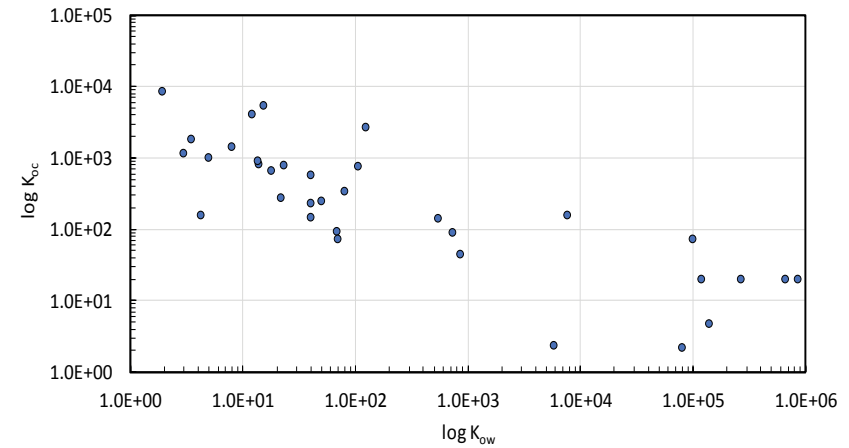

Figure 2: Relationship between soil organic carbon-water partition coefficient and octanol-water partition coefficient.

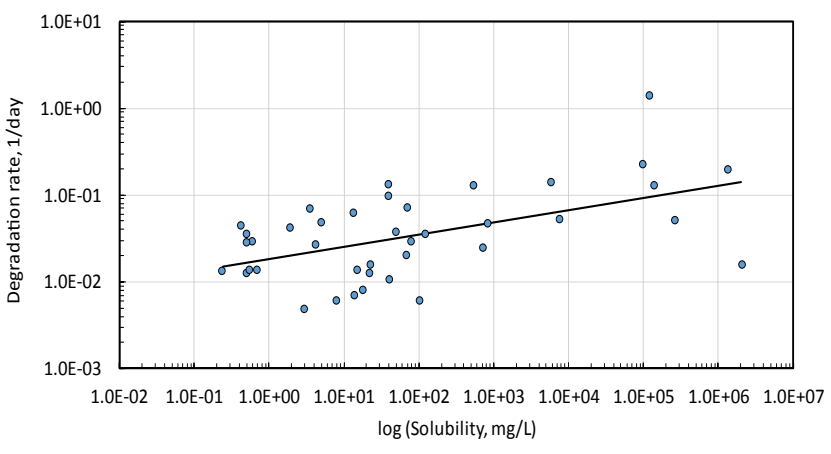

Figure 3: Relationship between solubility and degradation rate.

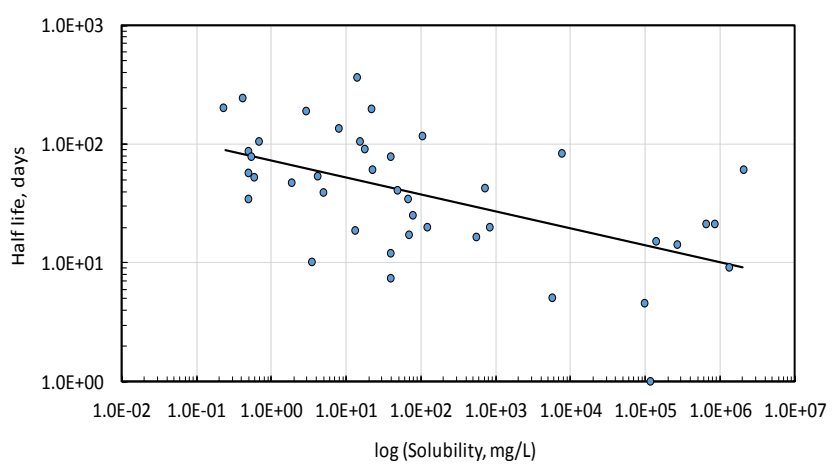

Figure 4: Relationship between solubility and half-life.

\begin{tabular}{|c|c|c|}
\hline Regression equation & $\mathbf{r}^{\mathbf{2}}$ & Figures \\
\hline $\log K_{o c}(\mathrm{~L} / \mathrm{kg})=0.421 \log S(\mathrm{mg} / \mathrm{L})+3.396$ & 0.757 & Figure 1 \\
$\log K_{o c}(\mathrm{~L} / \mathrm{kg})=0.660 \log K_{o w}+0.639$ & 0.878 & Figure 2 \\
\hline $\log K_{s}\left(\right.$ days $\left.{ }^{-1}\right)=0.140 \log S-1.735$ & 0.277 & Figure 3 \\
$\log t_{0.5}($ days $)=-0.143 \log S+1.861$ & 0.312 & Figure 4 \\
\hline $\log K_{s}\left(\right.$ days $\left.^{-1}\right)=-0.276 \log K_{o c}-0.761$ & 0.243 & Figure 5 \\
\hline $\log t_{0.5}$ (days) $=0.324 \log K_{o c}+0.748$ & 0.327 & Figure 6 \\
\hline
\end{tabular}

Table 2: Regression equations with $r^{2}$ values for various relationships.

known. If $S(\mathrm{mg} / \mathrm{L})$ or $K_{o w}$ value is available, the following equations can be used to predict the required mass of tire rubber per unit area (kg/ha):

$$
\begin{aligned}
& M_{a}=\frac{f \cdot Q_{r} \cdot t_{d} \cdot \rho_{t} \times 10^{3}}{(1-f) \cdot f_{o c} \cdot 10^{0.421 \log S(\mathrm{mg} / \mathrm{L})+3.396}} \\
& M_{a}=\frac{f \cdot Q_{r} \cdot t_{d} \rho_{t} \times 10^{3}}{(1-f) \cdot f_{o c} \cdot 10^{0.660 \log K_{o w}+0.639}}
\end{aligned}
$$

\section{Determination of tire rubber layer thickness for pesticide removal}

Eqs. (1-5) can be used to determine the thickness of a tire rubber layer required for pesticide removal. The material compositions of car tire (tire chip) and tire rubber (ground rubber) are summarized in Table 3 [44]. From Table 3, it can be assumed that the $f_{o c}$ values of car tire and tire rubber are 0.685 (rubber $47 \%+$ carbon black $21.5 \%$ ) and 0.93 (rubber $62 \%+$ carbon black $31 \%$ ), respectively [45].

Typical values of porosity, $\mathrm{n}$, range from 0.60 to 0.70 for uncompacted tire-derived aggregate (TDA) (size range between 50 $\mathrm{mm}$ to $305 \mathrm{~mm}$ ) [46] and from 0.45 to 0.55 for compacted TDA [47]. The specific gravity of tire rubber ranges between 1.02 and 1.27 , with 


\begin{tabular}{|c|c|c|c|c|c|c|c|}
\hline Type & Rubber & $\begin{array}{c}\text { Carbon } \\
\text { black }\end{array}$ & Metal & Textile & $\begin{array}{c}\text { Zinc } \\
\text { oxide }\end{array}$ & Sulfur & Additives \\
\hline Car tire & $47 \%$ & $21.5 \%$ & $16.5 \%$ & $5.5 \%$ & $1 \%$ & $1 \%$ & $7.5 \%$ \\
\hline $\begin{array}{c}\text { Tire } \\
\text { rubber }\end{array}$ & $62 \%$ & $31 \%$ & - & - & $2 \%$ & $1 \%$ & $4 \%$ \\
\hline
\end{tabular}

Table 3: Material compositions of passenger car tire in the European Union and tire rubber in Canada.

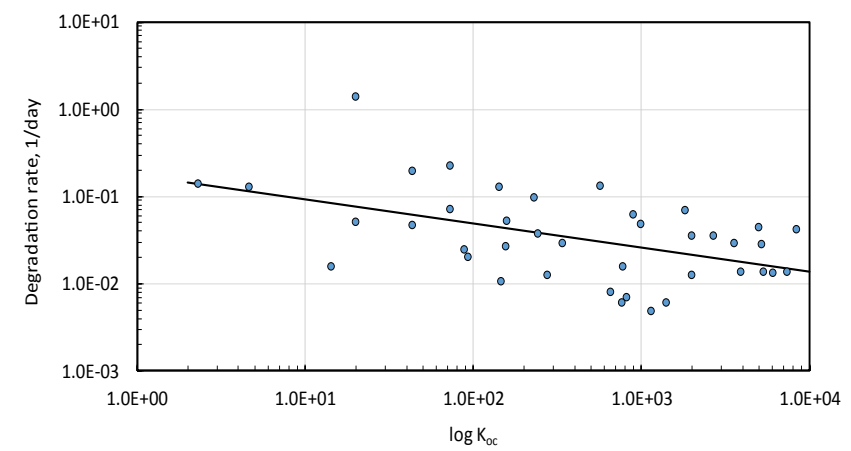

Figure 5: Relationship between soil organic carbon-water partition coefficient and degradation rate.

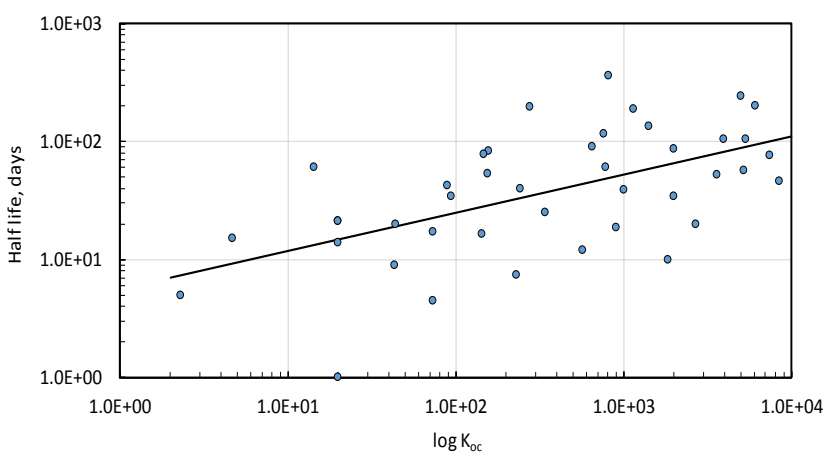

Figure 6: Relationship between soil organic carbon-water partition coefficient and half-life.

higher values corresponding to tire rubber containing steel inclusions $[26,48,49]$. For a tire rubber layer, assumed were the tire density of 1.2 $\mathrm{g} / \mathrm{cm}^{3}$, the porosity of 0.55 , and the $f_{o c}$ value of 0.75 . The design life was assumed to be five years, within which most pesticides adsorbed would be decomposed or desorbed. From the review of the reported property values for the pesticides, one year was thought to be sufficient for regeneration of tire rubber saturated with pesticides and fertilizers. Thus, a design life of five years provides a significant built-in factor of safety. Assuming a target removal of pesticides of $90 \%$ of the initial concentration and an infiltration rate of $2,000 \mathrm{~m}^{3} / \mathrm{ha} / \mathrm{yr}$, the tire rubber layer thickness was estimated using Eqs $(1,2)$.

Based on the calculated tire rubber layer thicknesses from this study, the pesticides were classified according to the layer thickness range as shown in Table 4. Among 51 pesticides evaluated, 37 pesticides (73\%) can be removed with a $\leq 20 \mathrm{~cm}$ thick tire rubber layer. As anticipated, the tire rubber layer thickness was linearly proportional to the infiltration rate. Thus, if the infiltration rate is $10,000 \mathrm{~m}^{3} / \mathrm{ha} / \mathrm{yr}$, a tire rubber layer five times the thickness computed for $2,000 \mathrm{~m}^{3} / \mathrm{ha} /$ yr is needed.

Runoff losses from Bermuda grass plots treated with 2,4-D, MCPP, and dicamba after $2.52 \mathrm{~cm}$ rainfall at 24 hours were measured to be $7.2 \%, 9.6 \%$, and $10.7 \%$, respectively [38]. In Table 4 , dicamba, the most difficult pesticide to remove, needed the thickest tire rubber layer, followed by MCPP and 2,4-D among 51 pesticides. Thus, the prediction of the tire rubber layer thickness matched well with the observation made in the field.

It may be impractical to install the tire rubber layer of $>200 \mathrm{~cm}$ to remove pesticides that are highly mobile. Fortunately, the three pesticides requiring the tire rubber layer $>200 \mathrm{~cm}$ tend to have relatively shorter half-lives than the pesticides that are readily adsorbed. To meet the requirements of both practicality and functionality, it is recommended that a tire rubber layer of $30 \sim 180 \mathrm{~cm}$ be used in applications in golf courses. In this recommended thickness range, the most mobile pesticide, dicamba can still be removed by $19 \sim 43 \%$.

In sandy areas (soil density of $2.65 \mathrm{~g} / \mathrm{cm}^{3}, f_{o c}$ of 0.005 , and porosity of 0.3 ), 96.4 times the tire rubber thickness would be required for $90 \%$ pesticide removal. This similar finding has been observed in the field [34]. Figure 7 shows the equivalent thickness multiplications to the base tire rubber thickness computed for Table 4 . It can be seen that if the organic carbon fraction, $f_{o c}$ is $>0.1$, the adsorption layer thickness can be significantly reduced. This is due to the adsorption of pesticides onto organic carbon present in tire rubber.

The correction factor was estimated for thickness at removal fractions from 0 to 0.99 and shown in Figure 8. The correction factor was set at 1 for a removal fraction of 0.9 . The correction factors for thicknesses at 0.95 and 0.99 were estimated to be 2.1 and 11. It can be seen that the correction factor increases sharply when the removal fraction becomes $>0.9$. Thus, it would be most practical if the desired removal fraction is $\leq 0.9$.

Sorption of organic compounds onto ground tires was not significantly affected by the presence of other organic or inorganic compounds under the conditions tested [17]. Thus, the layer thickness does not need to be increased for multiple pesticides to be removed. The maximum layer thickness determined for a pesticide should be the design thickness. Since it was found that the effects of $\mathrm{pH}$ and temperature on the sorption were insignificant, their effects can be ignored.

With regards to the long-term fate of chemicals in tire rubber layers, only $3.5 \% \sim 7.9 \%$ of organic compounds adsorbed in tire rubber were later desorbed [16]. Thus, when high levels of pesticides enter a tire rubber layer, they are adsorbed on to the tire rubber and subsequently slowly release or degrade, implying slow regeneration of sorption capacity. Furthermore, the partition coefficient after desorption tests were found to be two to 15 times greater than those obtained from sorption tests [16], inferring increased sorption capability. Thus, the assumption that it takes five years for tire rubber to be regenerated may be overly conservative. It is anticipated that the maximum regeneration may occur within less than one year. Granular activated carbon filters in a water treatment plant in Illinois [50], USA were not regenerated or replaced for over ten years, indicating natural regeneration occurring over time.

\section{Practical applications}

The impact of pesticides applied in golf courses on the surrounding environment is minimal if the proper pesticide application procedure is employed and the best management practices are implemented. However, if there is an environmentally sensitive area or the golf course is to be constructed and managed to the highest possible standard, the use of tire rubber can substantially benefit the process while also providing a use for an otherwise waste material. Lisi et al. [23] proposed the substitution of gravels in the putting green construction method proposed by US Golf Association (USGA) [51] with ground rubber for 


\begin{tabular}{|c|c|c|}
\hline Layer thickness, $d, \mathrm{~cm}$ & Pesticides $\left(t_{0.5}\right.$, days $)$ & Days \\
\hline \multirow{32}{*}{$d \leq 10 \mathrm{~cm}$} & MSMA sodium salt & 14 days \\
\hline & 2,4-D isooctyl ester & NA \\
\hline & glyphosate amine salt & 40 days \\
\hline & trifluralin & 137 days \\
\hline & chlorpyrifos & 46.4 days \\
\hline & benefin & 77 days \\
\hline & PCNP & 198.7 days \\
\hline & bensulide & 105 days \\
\hline & DCPA & 57 days \\
\hline & bensulide & 105 days \\
\hline & pendimethalin & 244 days \\
\hline & 2,4-D butoxyethylester & NA \\
\hline & oxadiazon & 105 days \\
\hline & chlorothalonil & 52 days \\
\hline & etridiozole & 20 day \\
\hline & glyphosate acid & 44 days \\
\hline & anilazine & 0.8 day \\
\hline & mancozeb & 87 days \\
\hline & maneb & 34 days \\
\hline & triophanate-methyl & 10 days \\
\hline & bendiocarb & 12 days \\
\hline & chloroneb & 135 days \\
\hline & benomyl & 187.3 days \\
\hline & MCPA ester & 38.5 days \\
\hline & iprodione & 18.5 days \\
\hline & fenarimol & 360 days \\
\hline & triclopyr & 60 days \\
\hline & DSMA & NA \\
\hline & propiconazole & 116 days \\
\hline & siduron & 90 days \\
\hline & ethofumesate & 25 days \\
\hline & isofenphos & 197.5 days \\
\hline \multirow{6}{*}{$10 \mathrm{~cm}<d \leq 20 \mathrm{~cm}$} & Diazinon & 40.1 days \\
\hline & carbaryl & 7.3 days \\
\hline & metalaxyl & 83.5 days \\
\hline & simazine & 53.5 days \\
\hline & atrazine & 78.5 days \\
\hline & fenamiphos & 16.5 days \\
\hline \multirow{4}{*}{$20 \mathrm{~cm}<d \leq 50 \mathrm{~cm}$} & Isazofos & 34 days \\
\hline & ethoprop & 42.3 days \\
\hline & triadimefon & 17 days \\
\hline & endothal & 4.5 days \\
\hline \multirow{2}{*}{$50 \mathrm{~cm}<d \leq 100 \mathrm{~cm}$} & 2,4-D acid & 20 days \\
\hline & 2,4-D dimethylamine salt & 9 days \\
\hline \multirow{5}{*}{$100 \mathrm{~cm}<d \leq 200 \mathrm{~cm}$} & Fosetyl al & 1 day \\
\hline & MCPA salt dimethylamine & 21 days \\
\hline & MCPA sodium salt & 14 days \\
\hline & MCPP amine (Mecoprop) & 21 days \\
\hline & triclopyr & 60 days \\
\hline \multirow{3}{*}{$d>200 \mathrm{~cm}$} & Trichlorfon & 15 days \\
\hline & dicamba acid & 19 days \\
\hline & dicamba salt & NA \\
\hline
\end{tabular}

\section{NA: Not available}

Table 4: Pesticides that are removed by $\geq 90 \%$ by tire rubber layer at various thickness. removal of nitrate present in fertilizers. Furthermore, since phosphorus can be removed by the reaction with iron released from steel wire in tires $[24,25]$, algal blooms in golf course ponds may be reduced. Tire rubber can also be used as a low-cost drainage backfill material to adsorb pesticides and fertilizers applied to greens, fairway, and tee boxes as proven by Cecich et al. [52] for retaining wall structures and CalRecycle [53] for various civil engineering applications. Along water bodies, a tire rubber layer can be installed as a filter zone to remove pesticides, nitrate, and phosphorous. By using tire rubber in strategically located areas as an adsorbent and filtering layer with proper engineering considerations and design, it is possible to construct more sustainable and environmentally-friendly golf course. This approach also creates the added benefit of recycling a few hundred thousands of scrap tires for beneficial reuse.

\section{Conclusions and Recommendations}

From the statistical analysis of the properties of 51 pesticides, the following conclusions can be drawn:

1. There was a strong relationship between solubility and soil organic carbon-water partition coefficient, $K_{o c}$, indicating that as the $K_{o c}$ value decreases the solubility increases. However, there were a few exceptions among pesticides used in golf courses such as glyphosate and MSMA sodium salt. These pesticides should be applied carefully to minimize transport to the environment.

2. From the relationships between solubility or $K_{o c}$ and degradation rate or half-life, it was found that the degradation rate increases or half-life decreases as the solubility increases or $K_{o c}$ decreases. This implies that highly mobile pesticides due to high solubility and $K_{o c}$ may not move long distance due to high degradation rate or low half-life.

From the estimation of the tire rubber layer thickness computation, the following conclusions can be drawn:

1. Out of 51 pesticides, 37 pesticides were estimated to be removed with the tire rubber layer thickness of $\leq 20 \mathrm{~cm}$ under a typical scenario.

2. There were three pesticides that require more than a $200 \mathrm{~cm}$ thick tire rubber layer. However, due to relatively low half-lives of $1 \sim 60$ days, it is anticipated that these pesticides are readily decomposed and thus the impact to the environment may be minimal.

3. If the organic carbon fraction, $f_{o c}$, is $>0.1(10 \%)$, the reaction layer thickness can be significantly reduced.

With respect to the application of tire rubber for the mitigation of pesticides and fertilizers from golf courses, the following recommendations can be made:

1. The use of tire rubber in golf courses will significantly lower the release of pesticides to the surrounding environment.

2. The potential applications of tire rubber include greens, fairways, tee boxes, bunkers, and wetlands in golf courses.

3. Various forms of tire rubber can be employed as filter layers, backfill materials, drainage packing materials, wetlands growth support layer fill materials, and lightweight fill materials for island greens and soft foundation areas.

4. If properly designed and installed, many scrap tires can be beneficially recycled in a golf course to make the golf course more sustainable and environmentally benign. 


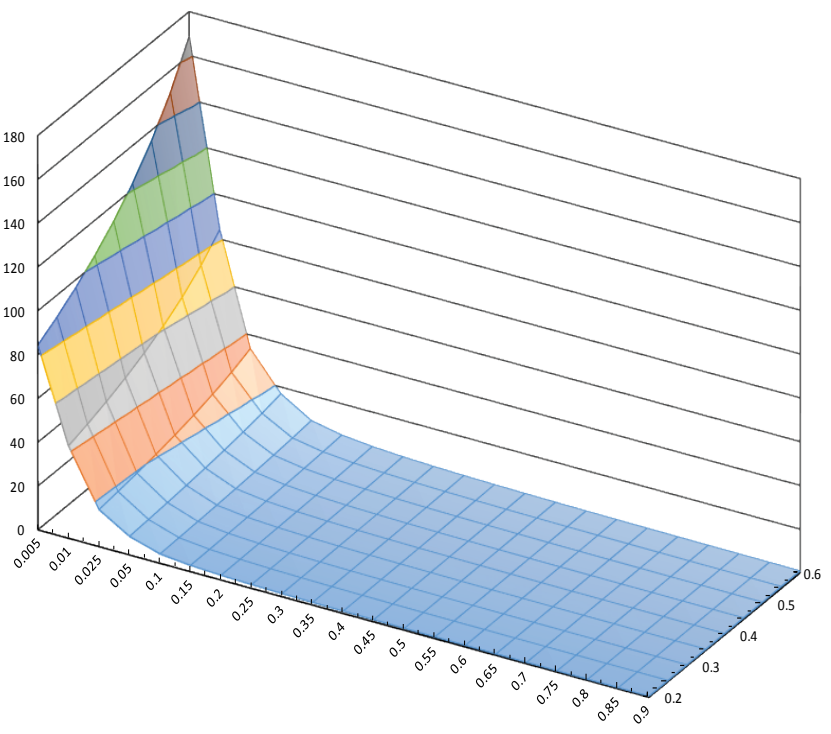

Figure 7: Equivalent distance multiplication for $90 \%$ pesticide removal by tire rubber at different organic carbon fraction and porosity.

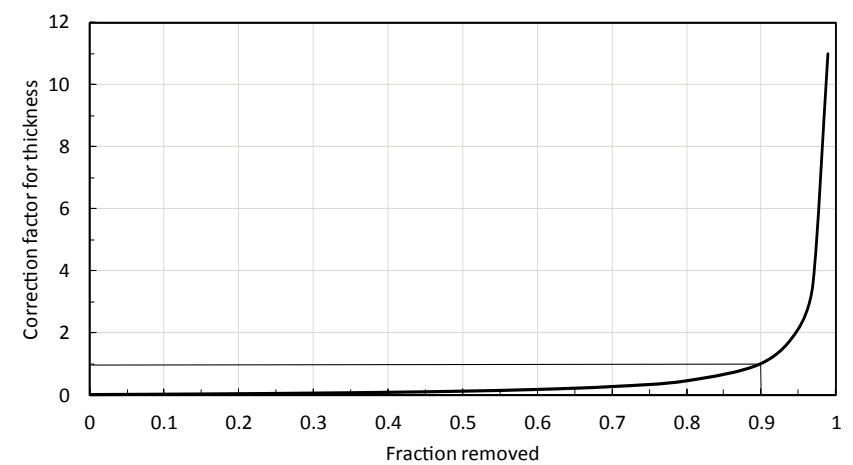

Figure 8: Correction factors for tire rubber layer thickness estimation at different removal fractions.

\section{References}

1. Rubber Manufactures Association (2009) Scrap Tire Markets in the United States.

2. US Environmental Protection Agency (2011) Municipal solids waste generation recycling and disposal in the United States: facts and figures for 2011.

3. Downs LA, Humphrey DN, Katz LE, Rock CA (1996) Water quality effects of using tire chips below the groundwater table. Department of Civil and Environmental Engineering, University of Maine.

4. Office of Environmental Health Hazard Assessment (2007) Recycled waste tires in playground and track products. Integrated Waste Management Board, Sacramento, CA, Publication 622-06-013.

5. US Environmental Protection Agency (2009) National primary drinking water regulations. EPA 816-F-09-004.

6. Zelibor JL (1991) Leachate from scrap tires: RMA TCLP Report. Education Seminar on Scrap Tire Management, Scrap Tire Management Council, Washington, DC, September 382-391.

7. Ealding W (1992) Final report on leachable metals in scrap tires. Virginia Department of Transportation Materials Division, Virginia Department of Transportation Scrap Tire Task Force.

8. Humphrey DN, Kantz LE, Blumenthal M (1997) Water quality effects of tire chip fills placed above the groundwater table. Testing Soil Mixed with Waste or Recycled Materials, ASTM STP 1275: 453-464.
9. Humphrey DN, Katz LE (2001) Field study of water quality effects of tire shreds placed below the water table. Proceedings of the Conference on Beneficial Use of Recycled Materials in Transportation Applications, Air and Waste Management Association, Pittsburgh. November 2001.

10. Reddy CM, Quinn JG (1997) Environmental chemistry of benzothiazoles derived from rubber. Environ. Sci Tech 31: 2847-2853.

11. Groenevelt PH, Grunthal PE (1998) Utilization of crumb rubber as a soil amendment for sports turf. Soil and Tillage Res 47: 1-2.

12. Park JK, Bontoux L, Holsen TM, Jenkins D, Selleck RE (1991) Permeation of polybutylene pipe and gasket material by organic chemicals. J Am Water Works Assoc 83: 71-78.

13. Glaza EC, Park JK (1992) Organic chemical contamination of potable water through gasket joints. J Am Water Works Assoc 84: 92-100.

14. Tyres International Recycling Environmental Solution (2015) Introduction to the used tyres recycling.

15. Kim JY, Park JK, Edil TB, Jhung JK (1994) Sorption capacity of ground tires for vapor phase volatile organic compounds. ASTM International Symposium on Volatile Organic Compounds (VOCs) in the Environment, Montreal, Quebec, Canada, PP: 17-19.

16. Park JK, Kim JY, Edil TB (1996) Mitigation of organic compound movement in landfills by a layer of shredded tires. Water Environ Res 68: 4-10.

17. Kim JY, Park JK, Edil TB (1997) Sorption of organic compounds in the aqueous phase onto tire rubber. J of Environ Eng ASCE 123: 827-835

18. Park JK, Kim JY, Madsen CD, Edil TB (1997) Retardation of volatile organic compound movement by a bentonite slurry cut-off wall amended with ground tires. Water Environ Res 69: 1022-1031.

19. Park JK, Kim JY, Edil TB, Huh M, Lee SH, et al. (2003) Suitability of shredded tires as a substitute for a landfill leachate collection medium. Waste Manag and Res 21: 278-289.

20. Gupta VK, Nayak A, Agarwal S, Chaudhary M, Tyagi I (2014) Removal of N (II) ions from water using scrap tire. Journal of Molecular Liquids 190: 215-222.

21. Scheels N, Park JK (1995) Grounds for odor removal. Water Environ and Technol 7: 48-51.

22. Wang $\mathrm{N}$ (2010) An investigation of $\mathrm{H}_{2} \mathrm{~S}$ adsorption mechanisms on tire derived rubber particles (TDRP'M). MS Thesis, lowa State University, p: 11550.

23. Lisi RD, Park JK, Stier JC (2004) Mitigating nutrient leaching with a sub-surface drainage layer of granulated tires. Waste Manag 24: 831-839.

24. Richter AY, Weaver RW (2004) Phosphorus reduction in effluent from subsurface-flow constructed wetlands filled with tire chips. Onsite Wastewater Treatment $X$, Proceedings of the Tenth National Symposium on Individual and Small Community Sewage Systems, Sacramento, California, ASAE, St. Joseph, MI, USA.

25. Chyan JM, Senoro DB, Lin CJ, Chen PJ, Chen IM (2013) A novel biofilm carrier for pollutant removal in a constructed wetland based on waste rubber tire chips. International Biodeterioration and Biodegrad 85: 638-645.

26. Humphrey DN, Manion WP (1992) Properties of tire chips for lightweight fill. Grouting, Soil Improv and Geosyn ASCE 2: 1344-1355.

27. Upton RJ, Machan G (1993) Use of shredded tires for lightweight fill Transportation Research Record No. 1422, Transportation Research Board Washington, DC, pp: 36-45.

28. Masad E, Taha R, Ho C, Papagiannakis T (1996) Engineering properties of tire/ soil mixtures as a lightweight fill material. Geotech Test J ASTM 19: 297-304.

29. Bosscher PJ, Edil TB, Kuraoka S (1997) Design of highway embankments using tire chips. J of Geotech and Geoenviron Eng ASCE 123: 295-304.

30. Tweedie JJ, Humphrey DN, Sandford TC (1998) Tire shreds as retaining wall backfill, active conditions. J of Geotech and Geoenviron Eng ASCE 124: 10611070.

31. Humphrey DN (1999) Civil engineering applications of tire shreds. Proc. of the Tire Industry Conference, Clemson University, pp: 3-5.

32. Organization of Economic Cooperation and Development (OECD) (2012) OECD Environmental Outlook to 2050, OECD Publishing.

33. Cohen S, Syrjcek A, Durborow T (1999) Water quality impacts by golf courses $\mathrm{J}$ of Environ Qual 28: 798-809. 
Citation: Park JK, Ye C (2016) Beneficial Use of Scrap Tires for Retardation of Pesticide Movement in Golf Courses. Adv Recycling Waste Manag 1: 107.DOI: 10.4172/2475-7675.1000107

34. Snow JT (1996) Loss of nitrogen and pesticides from turf via leaching and runoff. Proc 14th Australian Turfgrass Conference and Trade Exhibition, Melbourne, Australia.

35. Köck-Schulmeyer M, Vilagrasa M, López de AM, Céspedes-Sánchez $R$, Ventura F, et al. (2013) Occurrence and behavior of pesticides in wastewater treatment plants and their environmental impact. Sci of the Total Environ, pp: 466-476.

36. King KW, Harmel RD, Torbert HA, Balogh JC (2007) Impact of a turfgrass system on nutrient loadings to surface water. J Am Water Resour Assoc 37: 629-640.

37. Swancar A (1996) Water quality, pesticide occurrence, and effects of irrigation with reclaimed water at golf courses in Florida. US Geological Survey, WaterResources Investigations Report, pp: 95-4250.

38. Kearns CA, Prior L (2013) Toxic greens: a preliminary study on pesticide usage on golf courses in Northern Ireland and potential risks to golfers and the environment. WIT Transac on the Built Env 134: 173-182.

39. Li FR, Yang SP, Yu D, Wang HM, Chen Y, et al. (2013) Environmental pollution analysis and countermeasures of the golf course in Yangzonghai area. Adv Mater. Res 788: 283-287.

40. Haith DA (2010) Ecological risk assessment of pesticide runoff from grass surfaces. Environmental Science and Technology 44: 6496-6502.

41. Kenna MP (1995) what happens to pesticides applied to golf courses? USGA Green Section Record 33: 1-9.

42. Balogh JC, Walker WJ (1992) Golf course management \& construction: environmental issues. Lewis Publishers, pp: 268-277.

43. Sims GK (1991) The effects of sorption on the bioavailability of pesticides. London, Springer Verlag, pp: 119-137.
44. O'Shaughnessy VO, Garga VK (2000) Tire-reinforced earthfill. Part 3: Environ Assess Canadian Geotech J 37: 117-131.

45. Mavridow S, Oikonomou N (2011) Report on characteristics of tire rubber EU-LIFE+ Environment Policy and Governance, LIFE 09 ENV/GR/304 "ROADTIRE".

46. ASTM D 6270-08 (2012) Standard practice for use of scrap tires in civil engineering applications. American Society for Testing and Materials (ASTM).

47. Geosyntec Consultants (2008) Guidance manual for engineering uses of scrap tires. Geosyntec Project No. ME0012-11, 10015 Old Columbia Road, Suite A-200, Columbia, Maryland.

48. Bressette $T$ (1984) Used tire material as an alternative permeable aggregate. Report No. FHWA/CA/TL-84/07, Office of Transportation Laboratory, California Department of Transportation, Sacramento, California

49. Ahmed I (1993) Laboratory study on properties of rubber soils. Report No FHWA/IN/JHRP-93/4, Purdue University, West Lafayette, Indiana.

50. Soucie W, Sheen B (2007) Filter-to-waste optimization. American Water Works Association Journal 99: 148-157.

51. US Golf Association (2004) USGA recommendations for a method of putting green construction. US Golf Association Green Section Staff, Waco, TX, USA.

52. Cecich V, Gonzales L, Hoisaeter A, Williams J, Reddy K (1996) Use of shredded tires as lightweight backfill materials for retaining structures. Waste Management and Research 14: 433-451.

53. CalRecycle (2015) Tire-derived aggregate. California Department of Resources Recycling and Recovery (CalRecycle). 